\title{
BILANGAN KROMATIK LOKASI DARI GRAF SPINNER
}

\author{
CHINTIA DEVA RIANTI, NARWEN \\ Jurnal Matematika, \\ Fakultas Matematika dan Ilmu Pengetahuan Alam, Universitas Andalas, \\ Kampus UNAND Limau Manis Padang, Indonesia. \\ email : chintia.deva@yahoo.com
}

\begin{abstract}
Abstrak. Misalkan graf $G$ merupakan graf terhubung. Pewarnaan titik pada graf $G=(V, E)$ adalah suatu pemetaan $c: V \rightarrow \mathbb{N}$, dimana $\mathbb{N}$ adalah himpunan bilangan asli sedemikian sehingga untuk setiap $u, v \in V(G)$ yang bertetangga, berlaku $c(u) \neq c(v)$. Jika banyak warna yang digunakan sebanyak $k$, maka $G$ dikatakan mempunyai $k$-pewarnaan. Bilangan bulat terkecil $k$ sedemikian sehingga $G$ mempunyai suatu pewarnaan titik sejati disebut bilangan kromatik dari $G$, dinotasikan dengan $\chi(G)$. Misalkan $\Pi=\left\{S_{1}, S_{2}, \cdots, S_{k}\right\}$ merupakan partisi dari himpunan titik di $G$ ke dalam kelaskelas warna yang saling bebas, dimana $S_{i}$ merupakan himpunan titik-titik yang berwarna $i$ dengan $1 \leq i \leq k$. Representasi $v$ terhadap $\Pi$ disebut kode warna, dinotasikan $c_{\pi}(v)$, merupakan pasangan berurut dengan $k$ unsur yaitu
\end{abstract}

$$
c_{\Pi}(v)=\left(d\left(v, S_{1}\right), d\left(v, S_{2}\right), \cdots, d\left(v, S_{k}\right)\right),
$$

dimana $d\left(v, S_{i}\right)=\min \left\{d(v, x) \mid x \in S_{i}\right\}$, untuk $1 \leq i \leq k$. Jika setiap titik pada $G$ mempunyai kode warna yang berbeda terhadap $\Pi$, maka $c$ disebut pewarnaan lokasi. Minimum dari banyaknya warna yang digunakan pada pewarnaan lokasi dari graf $G$ disebut bilangan kromatik lokasi, dinotasikan $\chi_{L}(G)$. Pada tulisan ini akan dibahas tentang penentuan bilangan kromatik lokasi dari graf Spinner $C_{3} \times P_{2} \odot \bar{K}_{1}$.

Kata Kunci: Kelas warna, Kode warna, Bilangan kromatik lokasi, Graf Spinner

\section{Pendahuluan}

Teori graf merupakan salah satu kajian ilmu matematika. Graf disajikan dalam bentuk sederhana yaitu dalam bentuk titik dan sisi. Pengaitan titik-titik akan membentuk sisi sehingga membentuk suatu pola graf tertentu. Penggunaan teori graf sudah banyak diterapkan dalam berbagai ilmu antara lain jaringan komunikasi, transportasi, riset operasi, penentuan jarak terpendek antara dua buah kota, dan penentuan waktu tersingkat dalam pengiriman pesan antara dua buah terminal pada jaringan komputer.

Seiring dengan perkembangan ilmu pengetahuan, graf telah menghasilkan banyak kajian baru. Salah satu kajiannya yaitu tentang pewarnaan lokasi pada suatu graf. Kajian pewarnaan lokasi untuk pertama kalinya dibahas oleh Chartrand dkk (2002), yang dikembangkan dari dua konsep yaitu pewarnaan titik dan dimensi partisi pada graf. Pewarnaan graf dapat diterapkan dalam kehidupan sehari-hari seperti masalah penjadwalan kuliah dan masalah pada pengaturan waktu pada lampu lalu lintas disuatu persimpangan jalan. 


\section{Landasan Teori}

Bilangan kromatik lokasi pertama kali dikaji oleh Chartrand dkk[5]. Konsep ini merupakan pengembangan dari konsep dimensi partisi dan pewarnaan graf. Misalkan $\Pi=\left\{S_{1}, S_{2}, \cdots, S_{k}\right\}$, dimana $S_{i}$ merupakan himpunan titik-titik di $G$ yang berwarna i, untuk $1 \leq i \leq k$. Representasi $v$ terhadap $\Pi$ disebut kode warna, dinotasikan $c_{\pi}(v)$, merupakan vektor dengan banyak $k$ unsur yaitu

$$
c_{\Pi}(v)=\left(d\left(v, S_{1}\right), d\left(v, S_{2}\right), \cdots, d\left(v, S_{k}\right)\right),
$$

dimana $d\left(v, S_{i}\right)=\min \left\{d(v, x) \mid x \in S_{i}\right\}$, untuk $1 \leq i \leq k$. Jika setiap titik pada $G$ mempunyai kode warna yang berbeda terhadap $\Pi$, maka $c$ disebut pewarnaan lokasi. Minimum dari banyaknya warna yang digunakan pada pewarnaan lokasi dari graf $G$ disebut bilangan kromatik lokasi, dinotasikan $\chi_{L}(G)$.

Berikut ini adalah teorema dasar terkait bilangan kromatik lokasi. Himpunan tetangga dari titik $v$, dinotasikan dengan $N(v)$.

Teorema 2.1. [5] Misalkan c adalah suatu pewarnaan lokasi pada graf terhubung $G$. Jika $u$ dan $v$ adalah dua titik pada graf $G$ sedemikian sehingga $d(u, w)=d(v, w)$ untuk setiap $w \in V(G) \backslash\{u, v\}$, maka $c(u) \neq c(v)$. Dalam hal khusus, jika $u$ dan $v$ adalah titik-titik yang tidak bertetangga di $G$ sedemikian sehingga $N(u)=N(v)$, $\operatorname{maka} c(u) \neq c(v)$.

Bukti. Misalkan $c$ adalah suatu pewarnaan lokasi pada graf terhubung $G$ dan misalkan $\Pi=\left\{C_{1}, C_{2}, \cdots, C_{k}\right\}$ adalah partisi dari titik-titik $G$ kedalam kelas warna $C_{i}$. Untuk suatu titik $u, v \in V(G)$, andaikan $c(u)=c(v)$ sedemikian sehingga titik $u$ dan $v$ berada dalam kelas warna yang sama, misal $C_{i}$ dari $\Pi$. Akibatnya, $d\left(u, C_{i}\right)=d\left(v, C_{i}\right)=0$. Karena $d(u, w)=d(v, w)$ untuk setiap $w \in V(G) \backslash\{u, v\}$ maka $d\left(u, C_{i}\right)=d\left(v, C_{i}\right)$ untuk setiap $j \neq i, 1 \leq j \leq k$. Akibatnya, $c_{\Pi}(u)=c_{\Pi}(v)$ sehingga $c$ bukan pewarnaan lokasi. Dengan demikian, haruslah $c(u) \neq c(v)$.

Akibat 2.2. [5] Jika $G$ adalah suatu graf terhubung yang memuat suatu titik yang bertetangga dengan $k$ daun di $G$, maka $\chi_{L}(G) \geq k+1$.

Bukti. Misalkan $v$ adalah suatu titik yang bertetangga dengan $k$ daun $x_{1}, x_{2}, \cdots, x_{k}$ di $G$. Dari Teorema 2.1 setiap pewarnaan lokasi dari $G$ mempunyai warna berbeda untuk setiap $x_{i}, i=1,2, \cdots, k$. Karena $v$ bertetangga dengan semua $x_{i}$, maka $v$ harus mempunyai warna yang berbeda dengan semua daun $x_{i}$. Akibatnya, $\chi_{L}(G) \geq k+1$.

Misalkan terdapat graf siklus $C_{3}$ dan graf lintasan $P_{2}$. Hasil kali kartesius antara kedua graf tersebut adalah graf $C_{3} \times P_{2}$. Graf spinner $C_{3} \times P_{2} \odot \overline{K_{1}}$ diperoleh dari operasi korona antara graf $C_{3} \times P_{2}$ dengan komplemen dari graf lengkap $K_{1}$, yaitu $\overline{K_{1}}$. 
Pada Gambar 1 diberikan graf Spinner $C_{3} \times P_{2} \bigodot \overline{K_{1}}$. Dapat dilihat bahwa

$$
\begin{aligned}
V\left(C_{3} \times P_{2} \bigodot \overline{K_{1}}\right)= & \left\{x_{1}, x_{2}, \cdots, x_{6}\right\} \cup\left\{x_{11}, \cdots, x_{61}\right\} \\
E\left(C_{3} \times P_{2} \bigodot \overline{K_{1}}\right)= & \left\{x_{1} x_{2}, x_{2} x_{3}, x_{1} x_{3}\right\} \cup\left\{x_{4} x_{5}, x_{5} x_{6}, x_{4} x_{6}\right\} \cup\left\{x_{1} x_{4}, x_{2} x_{5}, x_{3} x_{6}\right\} \\
& \cup\left\{x_{i} x_{i 1} \mid 1 \leq i \leq 6\right\}
\end{aligned}
$$

\section{Bilangan Kromatik Lokasi dari Graf Spinner}

Pada bab ini akan dibahas tentang penentuan bilangan kromatik lokasi graf spinner $C_{3} \times P_{2} \odot \overline{K_{1}}$, seperti pada Teorema 2.1 berikut.

Teorema 3.1. $\diamond$ Misalkan terdapat graf $G \simeq C_{3} \times P_{2} \odot \overline{K_{1}} \cdot \operatorname{Maka} \chi_{L}(G)=4$.

Bukti. Misalkan $G \simeq C_{3} \times P_{2} \odot \overline{K_{1}}$. Akan ditunjukkan bahwa $\chi_{L}(G) \geq 4$. Pada graf $C_{3} \times P_{2} \odot \overline{K_{1}}$ terdapat dua graf $C_{3}$ yang dimisalkan dengan $C_{3}^{\prime}$ dan $C^{\prime \prime}{ }_{3}$, dimana titik dari graf $C_{3}^{\prime}$ adalah $x_{1}, x_{2}, x_{3}$ dan titik dari graf $C{ }^{\prime}{ }_{3}$ adalah $x_{4}, x_{5}, x_{6}$. Karena setiap titik pada graf $C_{3}$ bertetangga, maka banyak warna yang digunakan untuk pewarnaan lokasinya adalah 3 . Hal ini mengakibatkan $\chi_{L}(G) \geq 3$. Andaikan banyak warna yang digunakan pada graf $G$ adalah 3, maka akan selalu terdapat 2 titik dominan di $G$ yaitu pada titik $C_{3}^{\prime}$ dan $C{ }^{\prime \prime}{ }_{3}$ sedemikian sehingga tidak memenuhi syarat pewarnaan lokasi. Oleh karena itu, tiga warna tidak cukup untuk pewarnaan lokasi pada graf $G$. Akibatnya $\chi_{L}(G) \geq 4$.

Selanjutnya, akan ditunjukkan bahwa $\chi_{L}(G) \leq 4$ seperti pada Gambar 1 . Misalkan dikontruksikan pewarnaan sebagai berikut $c: V(G) \rightarrow\{1,2,3,4\}$, sedemikian sehingga

$$
\begin{aligned}
& c\left(x_{1}\right)=c\left(x_{31}\right)=1, \\
& c\left(x_{2}\right)=c\left(x_{11}\right)=c\left(x_{6}\right)=c\left(x_{41}\right)=2, \\
& c\left(x_{3}\right)=c\left(x_{21}\right)=c\left(x_{4}\right)=c\left(x_{51}\right)=3, \\
& c\left(x_{5}\right)=c\left(x_{61}\right)=4 .
\end{aligned}
$$

Berdasarkan konstruksi tersebut,diperoleh kelas warna sebagai berikut:

$$
\begin{aligned}
& S_{1}=\left\{x_{1}, x_{31}\right\}, \\
& S_{2}=\left\{x_{2}, x_{11}, x_{6}, x_{41}\right\}, \\
& S_{3}=\left\{x_{3}, x_{21}, x_{4}, x_{51}\right\}, \\
& S_{4}=\left\{x_{5}, x_{61}\right\} .
\end{aligned}
$$

Untuk menunjukkan bahwa $\chi_{L}(G) \leq 4$, cukup dengan menunjukkan bahwa pewarnaan titik terhadap $\Pi=\left\{S_{1}, S_{2}, S_{3}, S_{4}\right\}$ tersebut memenuhi syarat pewarnaan 


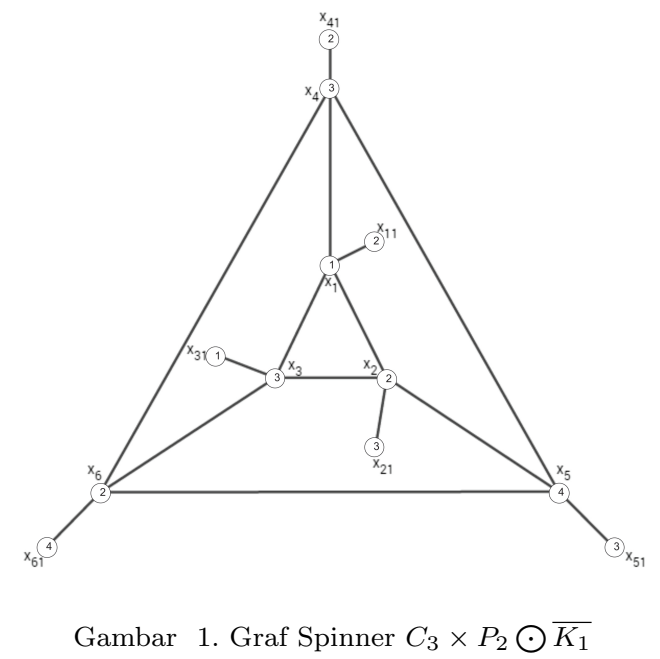

lokasi. Kode warna yang diperoleh adalah :

$$
\begin{aligned}
c_{\Pi}\left(x_{1}\right) & =\left(d\left(x_{1}, S_{1}\right), d\left(x_{1}, S_{2}\right), d\left(x_{1}, S_{3}\right), d\left(x_{1}, S_{4}\right)\right)=(0,1,1,2), \\
c_{\Pi}\left(x_{31}\right) & =\left(d\left(x_{31}, S_{1}\right), d\left(x_{31}, S_{2}\right), d\left(x_{31}, S_{3}\right), d\left(x_{31}, S_{4}\right)\right)=(0,2,1,3), \\
c_{\Pi}\left(x_{2}\right) & =\left(d\left(x_{2}, S_{1}\right), d\left(x_{2}, S_{2}\right), d\left(x_{2}, S_{3}\right), d\left(x_{2}, S_{4}\right)\right)=(1,0,1,1), \\
c_{\Pi}\left(x_{6}\right) & =\left(d\left(x_{6}, S_{1}\right), d\left(x_{6}, S_{2}\right), d\left(x_{6}, S_{3}\right), d\left(x_{6}, S_{4}\right)\right)=(2,0,1,1), \\
c_{\Pi}\left(x_{11}\right) & =\left(d\left(x_{11}, S_{1}\right), d\left(x_{11}, S_{2}\right), d\left(x_{11}, S_{3}\right), d\left(x_{11}, S_{4}\right)\right)=(1,0,2,3) \\
c_{\Pi}\left(x_{41}\right) & =\left(d\left(x_{41}, S_{1}\right), d\left(x_{41}, S_{2}\right), d\left(x_{41}, S_{3}\right), d\left(x_{41}, S_{4}\right)\right)=(2,0,1,2), \\
c_{\Pi}\left(x_{3}\right) & =\left(d\left(x_{3}, S_{1}\right), d\left(x_{3}, S_{2}\right), d\left(x_{3}, S_{3}\right), d\left(x_{3}, S_{4}\right)\right)=(1,1,0,2), \\
c_{\Pi}\left(x_{4}\right) & =\left(d\left(x_{4}, S_{1}\right), d\left(x_{4}, S_{2}\right), d\left(x_{4}, S_{3}\right), d\left(x_{4}, S_{4}\right)\right)=(1,1,0,1), \\
c_{\Pi}\left(x_{21}\right) & =\left(d\left(x_{21}, S_{1}\right), d\left(x_{21}, S_{2}\right), d\left(x_{21}, S_{3}\right), d\left(x_{21}, S_{4}\right)\right)=(2,1,0,2), \\
c_{\Pi}\left(x_{51}\right) & =\left(d\left(x_{51}, S_{1}\right), d\left(x_{51}, S_{2}\right), d\left(x_{51}, S_{3}\right), d\left(x_{51}, S_{4}\right)\right)=(3,2,0,1), \\
c_{\Pi}\left(x_{5}\right) & =\left(d\left(x_{5}, S_{1}\right), d\left(x_{5}, S_{2}\right), d\left(x_{5}, S_{3}\right), d\left(x_{5}, S_{4}\right)\right)=(2,1,1,0), \\
c_{\Pi}\left(x_{61}\right) & =\left(d\left(x_{61}, S_{1}\right), d\left(x_{61}, S_{2}\right), d\left(x_{61}, S_{3}\right), d\left(x_{61}, S_{4}\right)\right)=(3,1,2,0) .
\end{aligned}
$$

Karena setiap titik pada $G$ memiliki kode warna yang berbeda, maka $c$ merupakan pewarnaan lokasi pada graf $G$. Jadi, diperoleh $\chi_{L}(G) \leq 4$.

Dari pembuktian diatas diperoleh bahwa $\chi_{L}(G) \geq 4$ dan $\chi_{L}(G) \leq 4$, sehingga dapat disimpulkan bahwa $\chi_{L}(G)=4$.

\section{Kesimpulan}

Diperoleh bilangan kromatik lokasi pada graf $G=C_{3} \times P_{2} \odot \overline{K_{1}}$ adalah 4 .

\section{Ucapan Terima kasih}

Terima kasih kepada ibu Dr. Lyra Yulianti, ibu Dr. Des Welyyanti, ibu Monika Rianti Helmi, M.Si, dan ibu Dr. Arrival Rince Putri yang telah memberikan kritik 
dan saran dalam penulisan makalah ini.

\section{Daftar Pustaka}

[1] Asmiati, H. Assiyatun dan E. T. Baskoro. 2011. Locating chromatic number of Amalgamation of stars. ITB Journal of Science. 1: 1 - 8

[2] Baskoro, E. T. dan I. A. Purwasih. 2012. The locating chromatic number for corona product of graph. Southeast Asian Journal of Sciences. 1: $124-134$

[3] Bahtoei, A. dan B. Ommomi. 2012. On the locating chromatic number of cartesian product of graphs. Cornell University Library, http://arxiv.org/abd/1106.3452

[4] Bondy, J. A dan Murty, U.S.R. 1976. Graph Theory with Application. The Macmillan Press LTD, London

[5] Chartrand, G., D. Erwin, M. A. Henning, P.J. Slater dan P. Zhang. 2002. The locating chromatic number of a graph. Bull. Inst. Combin. Appl. 36: 89- 101

[6] Chartrand, G., dkk . 2003. Graphs of order n with locating-cromatic number $n$ - 1. Science Direct, Discrete Math. 269: 65 - 79 